\title{
Juridical Analysis of Collective Assets Sharing That Still in Bank Guarantee (Analysis of Mataram Religious Court Decision Number 0337 / Pdt.G / 2017 / PA.Mtr)
}

\author{
Septiandini Riadiljannah ${ }^{1} \quad$ Salim H. S Muhaimin $^{2}$ \\ 1.Graduate Program Student in Notary, Faculty of Law, Mataram University, Indonesia \\ 2.Lecturer of Faculty of Law, Mataram University, Indonesia
}

\begin{abstract}
The purpose of this study is to explain and analyze the status of joint assets that are still under bank guarantee when there is a divorce at the Religious Court and the distribution of joint assets that are still under bank guarantee when the divorce occurs. The research method used is normative legal research method. The approach used is the statutory approach, conceptual approach and case approach. The results of this study, First, the status of joint assets that are still under guarantee at the bank when a divorce occurs at the Religious Court is categorized as joint property as long as the marriage agreement is not specified otherwise. Second, the distribution of joint assets that are still under bank guarantee at the time of the divorce can be divided in half by each receiving a half of the joint assets as long as it is not specified in the marriage agreement and can be resolved through the competent court or through an agreement, if through an agreement it can be done by bearing together with the remaining installments that are still in progress, provide compensation to parties who do not wish to continue credit installments, or by transferring credit (over credit) to third parties.
\end{abstract}

Keywords: Joint Assets, Bank Guarantee, Credit.

DOI: $10.7176 / \mathrm{JLPG} / 107-05$

Publication date:March $31^{\text {st }} 2021$

\section{INTRODUCTION}

When divorced, a common problem is co-ownership. Many Indonesians believe that property in marriage automatically becomes a collective asset. This understanding is based on the assumption that by signing the marriage contract, the husband and wife are united in all aspects, including the issue of joint ownership. In fact, assets in a marriage include assets with different legal statuses, personal assets and joint assets.

The thing that most often happens in Indonesian society, who is currently mostly Muslim, is after the divorce incident, regarding spouses or sharing of joint assets between divorced husbands and wives. Whereas in marriage, it often happens that husbands and wives cannot see which inheritance is inherited, so what resolves disputes in settling disputes over joint assets is problems related to trade payables, one of which is the assets. still in the form of credit or still used as collateral at the bank. Whether the assets that are still in credit are included in joint assets or not. In matters relating to joint assets, there is also an opinion among the Panel of Judges in deciding cases of joint assets.

The case at the Mataram Religious Court with the Mataram Religious Court Decision Number 0337 / Pdt.G / 2017 / PA.Mtr suing joint assets that are still guaranteed by the bank, in this case the Home Ownership Credit (KPR), in this case among the joint assets that are being sued by the Convention Respondent / Plaintiff of the Reconvention (wife) is a house that is still on credit status at the Bank, purchased in 2013 in installments for 25 years at Bank BTN Mataram and under Legal Considerations. Mataram Religious Court Decision Number 0337 / Pdt.G / 2017 / PA.Mtr, the judge argued that the house that was still under credit was not joint property, so the claim against the Respondent / Plaintiff for Reconvention (wife) for an object in the form of a house located at Royal Kenari Housing J1. Merdeka Raya Karang Pule, Sekarbela Subdistrict, Mataram City as joint property was rejected. Even though when viewed in Article 35 paragraph (1) of Law Number 16 of 2019 concerning Amendments to Law Number 1 of 1974 concerning Marriage and Article 1 letter (f) of Presidential Instruction Number 1 of 1991 concerning the Spread of Compilation of Islamic Laws obtained during the bond marriage is a joint asset.

Based on the aforementioned background, this study aims to explain and analyze the status of joint assets that are still under bank guarantee at the time of divorce at the Religious Courts as well as to explain and analyze the distribution of joint assets that are still in bank ownership.

\section{RESEARCH METHOD}

This type of legal research uses normative legal research. The approach used in this research is the Legislative Approach, Conceptual Approach and Case Approach. Types and sources of legal materials used in this study are 
primary legal materials, which are binding legal materials, and consist of statutory regulations. Secondary legal materials are legal materials that can help analyze primary legal materials, such as draft laws, research results ${ }^{1}$ Tertiary legal materials are materials that provide guidance and explanation for primary and secondary legal materials $^{2}$ examples are the Big Indonesian Dictionary and the Law Dictionary. The technique of collecting legal materials was carried out by using secondary data collection methods, namely literature studies ${ }^{3}$ The analysis of legal materials was carried out by qualitative data analysis and the conclusion of this study was to use the deductive method.

\section{DISCUSSION}

A. Status of the Joint Property Bank which is still under guarantee when a divorce occurs at the religious court

1. Specification of Case of Collective Assets Still Under Bank Guarantee in Mataram Religious Court Decision Number 0337 / Pdt.G / 2017 / PA.Mtr

The Convention Applicant / Reconvention Defendant and the Convention Respondent / Reconvention Defendant are legal husband and wife based on the Islamic religion, who married on July 10, 2002. Disputes and disputes occurred continuously so that finally the Convention Applicant / Defendant from Reconvention filed a divorce application. to the Mataram Religious Court. The Convention Applicant / Defendant for Reconvention filed a divorce application on 8 August 2017 which has been registered at the Registrar's Office of the Mataram Religious Court with Number 0337 / Pdt.G / 2017 / PAMtr ${ }^{4}$ As long as the Convention Applicant / Defendant for Reconvention and the Respondent for the Convention / Defendant for Reconvention were married, several assets were collected and one of them in question was a house in BTN Royal Kenari Kav. 29 is located on Jl. Merdeka Raya Karang Pule, Sekarbela Subdistrict, Mataram City, which is still under guarantee from the bank, which is still on credit. The two of them bought the house when their second household was still harmonious and the Convention Applicant / Reconvention Defendant also admitted that there was indeed a house that he bought on credit in 2013 with 25 years of installments at Bank BTN Mataram, but the house has now been transferred (over credit ) to third parties. The house was purchased on credit for 25 years with a monthly deposit of Rp. 3,600,000 and the Convention Applicant / Reconvention Defendant was no longer able to pay credit deposits so that in the end the Convention Applicant / Reconvention Defendant took the house to another person.

On the other hand, the Convention Respondent / Plaintiff for the Reconvention admitted that it was true that the house located at the Royal Kenari Housing J1. Merdeka Raya Karang Pule Kec. Sekarbela Kota Mataram has been transferred to a third party (over credit) by the Convention Applicant / Reconvention Defendant but without the knowledge of the Convention Respondent / Reconvention Plaintiff. The house was over-credit by the Convention Applicant / Defendant on Reconvention around the ninth month of 2017.

During the examination by the Panel of Judges together with the parties in the case, the results of the examination found legal facts that the house located at the Royal Kenari Housing Jl. Merdeka Raya Karang Pule Kec. Sekarbela Kota Mataram and its contents have transferred their rights to another person, namely in the name of Weigh Nuarta who bought from the Convention Applicant / Defendant for Reconvention by paying an amount of Rp. 100,000,000 (one hundred million Rupiah) provided that the buyer continues the mortgage installments for the remaining installments. which is estimated to be 19 years from now with a monthly deposit of Rp. 3,500,000 (Three Million Five Hundred Thousand Rupiah) per month.

Then in the Judge's Legal Consideration, the Panel of Judges argued that the object of the dispute was a house at BTN Royal Kenari Kav. 29 is located on J1. Merdeka Raya Karang Pule, Sekarbela District, Mataram City, is not a Collective Property because the object of the dispute is obtained on credit, until it has not been paid off, in the form of Milkul Taam, perfect property or full ownership, by the Respondent / Plaintiff's lawsuit for the object in the form of a house in Royal Housing Kenari Jl. Merdeka Raya Karang Pule Kec. Sekarbela Kota Mataram as a Joint Property was rejected.

Based on the case specifications above, joint property in the form of a house of credit cannot be divided because the status as joint property is rejected by the Panel of Judges so that the Convention Applicant / Reconstruction Defendant (spouse) becomes the full owner of the house which is still guaranteed by the bank.

2.Analysis of the Decision of the Mataram Religious Court Number 0337 / Pdt.G / 2017 / PA.Mtr on the

\section{Status of Joint Assets Still Under Bank Guarantee}

In the above-mentioned Religious Court Decision, the object of the problem is joint property, one of which is a house that is still under credit at the bank, namely the house located at the Royal Kenari Housing Jl. Merdeka Raya Karang Pule Kec. Kota Sekarbela Mataram. The subjects are divorced husband and wife where the husband on behalf of Mei Endriawan S.H is the Convention Applicant / Reconvention Defendant and the wife is

\footnotetext{
${ }^{1}$ Soerjono Soekanto, Pengantar Penelitian Hukum, UI Press, Jakarta, 2006, hlm. 52.

${ }^{2}$ Amiruddin dan Zainal Asikin, Pengantar Metode Penelitian Hukum, Rajawali Press, Jakarta, 2016, hlm. 119.

${ }^{3}$ Muhaimin, Metode Penelitian Hukum, Mataram University Press, Mataram, 2020, hlm. 65.

${ }^{4}$ Putusan Pengadilan Agama Mataram Nomor 0337/Pdt.G/2017/PA.Mtr.
} 
on behalf of Herlina Asriningsih as the Convention Respondent / Reconvention Plaintiff.

The application for the distribution of joint assets is in accordance with Article 37 of Law Number 16 of 2019 concerning Amendments to Law Number 1 of 1974 concerning Marriage which explains that when a divorce occurs, joint assets are regulated in accordance with the respective statutory regulations. . In line with these provisions, if the marriage takes place in an Islamic manner, the distribution of joint assets is also guided by the provisions of Article 1 letter (f) of Presidential Instruction No.1 of 1991 concerning the Spread of Compilation of Islamic Law. , Book I of the Marriage Law, which regulates the following:

"Assets in marriage or syirkah are assets that are obtained either individually or with husband and wife while the marriage is in progress and hereinafter referred to as joint assets, without question being registered under anyone's name".

For the aforementioned reasons, the Convention Applicant / Defendant for Reconstruction asked the Panel of Judges in court to divide the proceeds of the joint venture into two equal parts between the Convention Applicant / Defendant on Reconstruction and the Convention Respondent / Reconvention Defendant. This is based on the provisions contained in Presidential Instruction No.1 of 1991 concerning the Dissemination of the Compilation of Islamic Law, Book I of Article 97 of the Marriage Law which states "Widows or widowers who are divorced are each entitled to half of the collective assets as long as the marriage agreement does not determine other."

The law allows a husband or wife to combine or accumulate divorce claims with claims to share assets together in one lawsuit. In the Civil Procedure Law, a lawsuit like this is allowed, which is known as the Accumulation of Claims in the Religious Courts. ${ }^{1}$

The trial trip is in accordance with the mechanism determined by the existing regulations. Such as the mediation process carried out by the Panel of Judges to reconcile the Convention Respondent / Reconvention Plaintiff and Convention Applicant / Reconvention Defendant in accordance with the Regulation of the Supreme Court of the Republic of Indonesia Number 1 of 2016 concerning Mediation Procedures in Courts as stipulated in Article 3 paragraph (2): "The judge examining the case in the consideration of the verdict must state that the case has been attempted for reconciliation through mediation by mentioning the name of the mediator", however the mediation that was pursued by the Convention Applicant / Reconvention Defendant and the Convention Respondent / Reconvention Defendant was unsuccessful.

The decisions issued by the judiciary in their respective levels have differences, this difference is due to different panels of judges who handle them at each level. Different panels of judges, different products issued. The decisions issued by the panel of judges at each level are of course with ideal legal considerations so that they are expected to bring justice. Legal considerations themselves contain analysis, argumentation, opinion or legal conclusions from the judge examining the case ${ }^{2}$

Mataram Religious Court Decision Case Number 0337 / Pdt.G / 2017 / PA.Mtr Panel of Judges assessed that assets that are still related to third parties cannot be categorized as joint assets before the property is paid off and becomes full ownership. . Asset conditions that are still related to third parties cannot be shared and in response to this situation the assets cannot be accepted as joint assets but become the responsibility of the main debtor making installments, in this case the Convention Applicant. / Defendant on Reconvention.

Differences of opinion between one Judge and another Judge in deciding or deciding cases in court often occur, Judges are not just mouths of law or mouth of the law, but Judges are responsible for upholding the law, so that Judges' decisions must reflect justice, fairness and benefits, as well as legal certainty. ${ }^{3}$

One example of differences in opinion or interpretation of the Judge's decision was the Semarang Religious Court Decision Number 2658 / Pdt.G / 2013 / PA.Smg which gave the status of joint assets in the form of a house that was still under bank guarantee., in this case, credit. In the Judge's Decision, the Panel of Judges determined the share of each Plaintiff and Defendant in joint assets in which the Plaintiff received a $30 \%$ share and the Defendant received $70 \%$ based on considerations of Article 97 and Article 229 of the Compilation of Islamic Law. If it is not divided naturally, the joint assets are sold for auction in public and 30\% of the proceeds will be handed over to the Plaintiff and $70 \%$ for the Defendant's share.

Thus it can be seen that there are differences of opinion by the Panel of Judges on each decision so that the comparison to the Mataram Religious Court Decision Number 0337 / Pdt.G / 2017 / PA.Mtr and the Semarang Religious Court Decision Number 2658 / Pdt.G / 2013 / PA.Smg raises a different verdict. Mataram Religious Court Decision Number 0337 / Pdt.G / 2017 / PA.Mtr rejected the status of joint property of the house which was still in credit because it had not formed perfect property and was still related to third parties, while the Semarang Religious Court Decision Number 2658 / Pdt.G / 2013 /PA.Smg grants the status of the joint assets of

\footnotetext{
${ }^{1}$ Astriani Van Bone, "Penyelesaian Sengketa Harta Bersama Berstatus Agunan Dalam Perkara Perceraian Di Pengadilan Negeri", Law Jurnal, Vol. 5, No. 5, Juli 2017: hlm. 83.

${ }^{2}$ M. Yahya Harahap, Hukum Acara Perdata, Sinar Grafika, Jakarta, 2014, hlm. 809.

${ }^{3}$ Bercah Pitoewa, "Kewenangan Komisi Yudisial dalam Rangka Pengawasan Hakim Guna Melaksanakan Amanat UUD 1945", Jurnal Hukum Fakultas Hukum Universitas Yarsi, Vol.1, No.3, 2013: hlm. 220.
} 
the house which are still under bank guarantee as joint assets. Therefore, the joint property in question in the Mataram Religious Court Decision Number 0337 / Pdt.G / 2017 / PA.Mtr cannot be divided in two because its status was rejected by the Panel of Judges while the Semarang Religious Court Decision Number 2658 / Pdt.G / 2013 / PA .Smg joint assets in the form of credit houses can be shared because their status as joint assets has been granted by the Panel of Judges.

In enforcing the law, there must always be elements that need to be considered, namely: legal certainty (rechtsicherheit), benefit (zweckmassigkeit) and justice (gerechttigkeit). Thus, if the judge wants to decide a case, then the basis must be on these three elements ${ }^{1}$ In addition, the panel of judges also has a legal umbrella to carry out their duties and authorities in the court, as stated in Law No. 48 of 2009 concerning Judicial Power Article 1 paragraph (1) "Judicial power is the power of an independent state to administer justice for enforcement. law and justice based on Pancasila and the 1945 Constitution of the Republic of Indonesia, for the sake of the implementation of the State of Law of the Republic of Indonesia "

The existing legal umbrella does not allow the panel of judges to act arbitrarily in carrying out their duties, it does not mean that judges can just decide, there are rules that must be observed. However, in the name of freedom, the Judge can abuse his power and act arbitrarily. For this reason, certain limitations must be created without sacrificing the principle of freedom as the essence of judicial power, namely ${ }^{2}$ :

1. The judge decides according to the law.

Each decision, the judge must be able to clearly demonstrate the legal provisions applied in a concrete case.

2. Judges decide individually to provide justice.

Judges make it possible to interpret, carry out legal construction, and even do not apply or override any applicable legal provisions.

3. In carrying out interpretation, construction, or discovering laws, Judges must stick to general principles of law and general principles of justice.

4. It must be something that supports taking action against arbitrary judges or abusing their freedom

In the case of joint assets, these assets will become joint assets if there is no agreement regarding the status of the assets prior to their existence at the time of the marriage, unless the assets obtained are obtained from gifts or inheritance or the inheritance of each husband and wife owned before the marriage is carried out as explained Article 35 paragraph (2) of Law Number 16 of 2019 concerning Amendments to Law Number 1 of 1974 concerning Marriage, that the assets of each husband or wife and the assets obtained by each as a gift or inheritance are below control of each as long as the parties do not determine otherwise ${ }^{3}$

In Article 37 of Law Number 16 of 2019 concerning Amendments to Law Number 1 of 1974 concerning Marriage regarding the distribution of joint assets, it is handed over to the parties between the divorced husband and wife, the parties who determine which law and what law will be enforced to share the common assets. If there is no agreement between the ex-husband and wife, the judge in court can consider according to a proper sense of justice ${ }^{4}$ What becomes the Judge's consideration in the case of the decision on joint property is proof of whether there is true joint property in the marriage, at what time the property is acquired by the husband or wife, whether before marriage or after marriage. Who gave the assets, whether obtained from gifts or gifts from the parents of the husband or wife. Is there any debt during marriage that can affect the distribution of assets in gono gini (in the form of installments). Are there any inherited assets that are used as joint assets, for example the belongings of a husband or wife which are then sold and made into joint assets.

It can be said that joint assets in marriage would be good to first examine whether the marriage uses a marriage agreement or not. The presence or absence of a marriage agreement will determine how both assets and debts should be arranged in a marriage 5

As in the case of the Mataram Religious Court Decision Number 0337 / Pdt.G / 2017 / PA.Mtr on the home ownership credit (KPR) obtained when the husband and wife are still married and between the two parties there is no marriage agreement so that according to the author, the house that is still on credit is a joint asset because joint debt is included in the category of joint assets based on the provisions of Article 91 of Presidential Instruction No.1 of 1991 concerning the Dissemination of the Compilation of Islamic Law, Book I of Marriage Law which explains that joint assets can be in the form of tangible objects. or intangible, but by the Judge of the Mataram Religious Court in Legal Considerations the Judge stated that the house was not a joint property. This is because there is still something to do with a third party, in this case a bank.

\footnotetext{
${ }^{1}$ Sudikno Mertokusumo, Bab-Bab Tentang Penemuan Hukum, Citra Aditya, Bandung, 1993, hlm. 9.

${ }^{2}$ A Salman Maggalatung, "Hubungan antara Fakta, Norma, Moral dan Doktrin Hukum dalam Pertimbangan Putusan Hakim", Jurnal Cita Hukum. Vol. 2, No. 2, Desember 2014: hlm. 188.

${ }^{3}$ A. Damanhuri, Segi-Segi Hukum Perjanjian Perkawinan Harta Bersama, Mandar Maju, Bandung, 2012, hlm.28-29.

${ }^{4}$ J. Satrio, Hukum Harta Perkawinan, Citra Aditya Bakti, Bandung, 1991, hlm. 17.

5 Julius Martin Saragih, Yunanto, Herni Widanarti, "Pertanggungjawaban Hutang-Hutang Persatuan Setelah Putusnya Perkawinan", Diponegoro Law Jurnal, Vol. 6, No. 1, 2017: hlm. 6.
} 
According to the author, if there is a lawsuit for the distribution of joint assets in which there are objects that are still in the credit stage, even though their ownership is in the name of the Convention Applicant / Reconvention Defendant or Convention Respondent / Reconvention Plaintiff, it is still divided in two for the problem of payment. Husbands and wives who commit legal acts in the form of a credit agreement by making joint assets the object of collateral have the same obligation to repay the credit. Since the credit agreement arises in the form of a marriage bond, repayment must be made by taking part of the joint property. Because in a marriage, it is not only property that is created but debt will also exist in the marriage. Therefore, if a marriage breaks up due to divorce for a joint property lawsuit, debt is also a part that must be in a joint property claim because it will be calculated and included in the decision later.

The burden of debt that is delegated to one party certainly seems unfair if only seen from one side. However, the authors see that the decision issued by the Mataram Religious Court is still inaccurate because it is clear in the Compilation of Islamic Law and the Marriage Law that joint assets are assets obtained while in a marriage bond even though when viewed from the Law on Judicial Powers, Judges given the freedom to decide a case. Moreover, if it is seen that the house ownership credit (KPR) has been transferred or over credit by the Convention Applicant / Reconvention Defendant to a third party and the wife does not know about the transfer under the hands, so that when the status of joint assets is rejected by the Panel of Judges, the the ownership rights to the house are the Convention Applicant / Reconvention Defendant. Therefore, according to the author, there is a need for justice for this.

According to the author, the Panel of Judges in deciding the case was not in accordance with the provisions of positive law, namely the Marriage Law and the Compilation of Islamic Laws. The decision does not contain justice, in which the decision is more favorable to one of the parties, namely the Convention Applicant / Reconvention Defendant who has full rights to the house in question even though the house was obtained while both were still married and the results of the efforts of the Convention Applicant / The Defendant of the Reconvention and the Respondent of the Convention / Defendant of the Reconvention. Therefore, if the Judge's consideration states that the status of a house that is still under credit is categorized as joint property, according to the author, it will provide more justice to divorced husbands and wives even though later the distribution will not be the same in number between the two.

The author's analysis in reviewing and examining the Mataram Religious Court Decision Number 0337 / Pdt.G / 2017 / PA.Mtr is by looking at the provisions of Article 35 paragraph (1) of Law Number 16 of 2019 concerning Amendments to Law Number 1 of 1974 concerning Marriage and Article 1 letter (f) Presidential Instruction Number 1 of 1991 concerning Dissemination of the Compilation of Islamic Law which states that assets obtained during the marriage bond are shared assets and in the Mataram Religious Court Decision Number 0337 / Pdt.G / 2017 / PA.Mtr home the question is obtained while still in the marriage bond.

\section{B. Sharing of Collective Assets which are still under Bank Guarantee when a divorce occurs}

The authority of husband and wife over joint assets can be seen in Article 36 paragraph (1) of Law Number 16 of 2019 concerning Amendments to Law Number 1 of 1974 concerning Marriage, which stipulates that regarding joint assets, husband and wife can act with second consent. both sides. This means that the authority or power or rights of husband and wife are equal. Therefore husband or wife can use or take legal action against their joint property, but on condition that there must be the consent of the other party (husband / wife) because there is a right of that party also over it. ${ }^{1}$ Husband and wife jointly have the right to joint property because of the equal position of husband and wife in the household and in the community. As emphasized in Article 31 paragraph (1) of Law Number 16 of 2019 concerning Amendments to Law Number 1 of 1974 concerning Marriage, the rights and position of the wife are equal to other rights of the husband's position in the household and the association of living together in the Public. As a result of the equal position of husband and wife, authority over joint property is equal.

In Article 35 paragraph (1) of Law Number 16 of 2019 concerning Amendments to Law Number 1 of 1974 concerning Marriage, it is stated that assets obtained during marriage become joint assets. Joint assets can be obtained either individually or with husband and wife in a marriage bond. In the status of husband and wife who are bound by a legal marriage, even though the assets are obtained from the livelihood of a husband / wife, the other spouse is also entitled to the joint property. These assets become joint assets without question being registered under anyone's name. If the husband and wife enter into a marriage agreement, then the assets acquired during the marriage period are their respective rights. This marriage agreement is made simultaneously with the marriage. In its development, the marriage agreement can also be agreed upon after the marriage is carried out.

Even though the divorce requested by the Religious Court has been granted by the Panel of Judges, this

\footnotetext{
${ }^{1}$ Abraham Lombogia, "Pembebanan Hak Tanggungan Atas Harta Bersama Suami Dan Isteri Dihubungkan Dengan Undang-Undang No. 1
} Tahun 1974”, Lex Privatum, Vol. 2, No. 3, Oktober, 2014: hlm. 86. 
decision still leaves problems with the status of the KPR house which is joint property. Home purchases made using the KPR (Home Ownership Credit) installment method must also be made in accordance with applicable regulations. Property purchases using the KPR method must be in the name of the applicant. This means that if the husband becomes the backbone of the family to earn a living, then the ownership of the house becomes in his name. ${ }^{1}$ This is in accordance with the case in the Mataram Religious Court Decision Number 0337 / Pdt.G / 2017 / PA.Mtr, where the ownership of the house was in the name of the Convention Applicant / Reconvention Defendant (husband).

When viewed from various kinds of literature, doctrines, jurisprudence and practice, the sharing of joint assets in the form of KPR houses can also be carried out on a non-litigation basis. This step is taken by striving for peace to produce an agreement between the husband and wife. The peace is stated in the deed either under hand or notarized. To provide legal certainty as well as in terms of dealing with other parties, it should be made in a notarized manner. Making a notarized peace deed will be easier for the parties to make legal relations with other parties related to joint assets ${ }^{2}$. In sharing the assets together, the parties can distribute the marital assets, namely by filing a lawsuit at the court where the Judge will decide the distribution of the marital assets. However, the parties can also make the distribution of marital assets before a notary based on mutual agreement. This will further reduce costs in the trial. ${ }^{3}$ In sharing the assets together, the parties can distribute the marital assets, namely by filing a lawsuit at the court where the Judge will decide the distribution of the marital assets. However, the parties can also make the distribution of marital assets before a notary based on mutual agreement. This will further reduce costs in the trial: ${ }^{4}$

1. After the divorce, credit to joint assets continues. The remaining installments that are still in progress are shared between the ex-husband and wife in a proportionate amount based on the agreement of the parties. When the assets have been paid and bought and sold, the proceeds from the sale are divided according to the contribution of each party so far.

2. Provide compensation to parties who do not wish to continue credit installments. With legal consequences, the asset becomes the property of the party that continues the credit payment for the asset. For example, when a former husband and wife were divorced, they still had mortgage payments in the bank for 5 years. If the ex-husband wishes to own the house, in addition to being obliged to settle the remaining credit that is still ongoing, the ex-husband is also obliged to return $50 \%$ of the total installments paid to his ex-wife. This is a form of compensation for the share of joint assets that belong to the ex-wife.

3. By transferring credit (over credit) on the asset to a third party and the money obtained from the transfer of credit is divided between the ex-husband and wife. The money obtained from the transfer of credit is considered as joint assets as a substitute for the previous assets.

If the settlement of the joint property problem cannot end in agreement or peace, it must be carried out through a lawsuit to the court. The Religious Courts for Muslims and the State Courts for those who are not Muslims. Collective property lawsuit in essence can be filed simultaneously with a divorce case. In the event that a joint property lawsuit is not filed simultaneously with a divorce suit, then the claim for joint property settlement can be filed after the divorce suit is granted by the court.

As happened in the case in the Mataram Religious Court Decision Number 0337 / Pdt.G / 2017 / PA.Mtr where what was questioned by the parties was a house whose status was still on credit at the bank. The reason is, the status of joint assets in the form of houses that are still under guarantee from the bank is rejected by the Panel of Judges so that the joint assets cannot be shared.

In Article 92 of Presidential Instruction No.1 of 1991 concerning Dissemination of Compilation of Islamic Law, Book I of Marriage Law husband or wife is not allowed to sell or transfer joint assets. Regarding this joint property, husband or wife can only act if they have the consent of their legal marriage partner, where this arrangement is also contained in Article 36 paragraph (1) of Law Number 16 of 2019 concerning Amendments to Law Number 1 of 1974 concerning Marriage.

If the settlement of the joint property problem cannot end in agreement or peace, it must be carried out through a lawsuit to the court. The Religious Courts for Muslims and the State Courts for those who are not Muslims. Collective property lawsuit in essence can be filed simultaneously with a divorce case. In the event that a joint property lawsuit is not filed simultaneously with a divorce suit, then the claim for joint property settlement can be filed after the divorce suit is granted by the court.

As happened in the case in the Mataram Religious Court Decision Number 0337 / Pdt.G / 2017 / PA.Mtr

${ }^{1}$ Isnaini Khoirunisa, https://www.rumah.com/berita-properti/2016/5/125986/beli-properti-sebaiknya-atas-nama-suami-atau-istri, diakses tanggal 13 Januari 2021, Pukul 21.30 WITA.

2 Junadi D. Kamil, https://rumahhokie.com/beritaproperti/rumah-kpr-jadi-harta-gono-gini-setelah-perceraian-begini-penyelesaiannya/, diakses tanggal 13 Januari 2021, Pukul 21.30 WITA.

3 Julius Martin Saragih, Yunanto, Herni Widanarti, "Pertanggungjawaban Hutang-Hutang Persatuan Setelah Putusnya Perkawinan", Diponegoro Law Jurnal, Vol. 6, No. 1, 2017: hlm. 9.

${ }^{4}$ Fairus Harris, https://kantorpengacara.co/penyelesaian-kredit-properti-ketika-terjadi-perceraian/, diakses tanggal 12 Januari 2021, Pukul 20.00 WITA. 
where what was questioned by the parties was a house whose status was still on credit at the bank. The reason is, the status of joint assets in the form of houses that are still under guarantee from the bank is rejected by the Panel of Judges so that the joint assets cannot be shared.

In the Mataram Religious Court Decision Number 0337 / Pdt.G / 2017 / PA.Mtr, the Convention Applicant / Reconvention Defendant (husband) acted without the consent of the Convention Respondent / Reconvention Plaintiff (wife), namely by transferring to a third party, so that it was not appropriate or violating the provisions of Article 36 paragraph (1) of Law Number 16 of 2019 concerning Amendments to Law Number 1 of 1974 concerning Marriage and Article 92 of Presidential Instruction Number 1 of 1991 concerning Dissemination of Compilation of Islamic Law, Book I of Marriage Law. So that even though the joint property in the form of a credit house has been transferred to a third party, the house transfer is considered invalid according to law and can be canceled because it is done under the hands and without the consent of the wife as a spouse or from the bank as the main creditor. In addition, because the object to be transferred is a house, this is based on Article 8 Paragraph (1) of Law Number 4 of 1996 concerning Mortgage Rights which determines that the giver of security rights is an individual or legal entity that has the authority to perform legal actions. the object of the related mortgage right. In the mortgage rights, a debtor who does not have a marriage agreement is deemed not to have the authority to grant mortgages without the consent of his husband or wife. Failure to fulfill the terms of the agreement violates the subjective conditions stipulated in Article 1320 of the Civil Code, so that the agreement can be canceled.

Regarding the case in the Mataram Religious Court Decision, the status of joint assets should be granted by the Panel of Judges so that the house can be divided between husband and wife even though it has been transferred to a third party. Because it has been transferred to a third party and there is no consent from the wife, according to the author, the wife still has rights to the joint property. If only the status of joint property can be granted by the panel of judges, the husband's party can ask for compensation for the result of the change of house to a third party. This provides more justice and legal certainty to both parties.

\section{CONCLUSION}

1. The status of joint assets that are still under guarantee at the bank when a divorce occurs at the Religious Court is categorized as joint property as long as the marriage agreement does not specify otherwise. Regarding the Decision of the Mataram Religious Court Number 0337 / Pdt.G / 2017 / PA.Mtr which refuses the status of home ownership credit (KPR) as joint property, this is not in accordance with the provisions in positive law, namely the Marriage Law and the Compilation of Islamic Law because of credit. Home ownership (KPR) was obtained while still in a marriage bond which was based on Article 35 paragraph (1) of Law Number 16 of 2019 concerning Amendments to Law Number 1 of 1974 concerning Marriage and Article 1 letter (f) of Presidential Instruction Number 1 of 1991 concerning the Dissemination of the Compilation of Islamic Law which states that assets obtained during the marriage bond are shared assets. So that it has not provided justice for both parties.

2. Distribution of joint assets that are still under the guarantee of the bank when the divorce occurs is divided by each receiving half of the joint assets as long as it is not stipulated in the marriage agreement and can be resolved through the competent court or by agreement. If through the court, it must be stated in the court's verdict. The court's decision then becomes the basis for the bank or notary to take legal steps against joint assets, including if the property is to be sold by one of the parties and if through an agreement it can be done by sharing the remaining installments that are still in progress, providing compensation to parties who do not. are pleased to continue credit installments, or by transferring credit (over credit) to third parties. Regarding the Mataram Religious Court Decision Number 0337 / Pdt.G / 2017 / PA.Mtr, joint property cannot be shared because according to the Panel of Judges it is not a joint property.

\section{REFFERENCES}

Book

A. Damanhuri, Segi-Segi Hukum Perjanjian Perkawinan Harta Bersama, Mandar Maju, Bandung, 2012.

Amiruddin dan Zainal Asikin, Pengantar Metode Penelitian Hukum, Rajawali Press, Jakarta, 2016.

J. Satrio, Hukum Harta Perkawinan, Citra Aditya Bakti, Bandung, 1991.

M. Yahya Harahap, Hukum Acara Perdata, Sinar Grafika, Jakarta, 2014.

Muhaimin, Metode Penelitian Hukum, Mataram University Press, Mataram, 2020.

Soerjono Soekanto, Pengantar Penelitian Hukum, UI Press, Jakarta, 2006.

Sudikno Mertokusumo, Bab-Bab Tentang Penemuan Hukum, Citra Aditya, Bandung, 1993.

\section{Journal}

A. Salman Maggalatung, "Hubungan antara Fakta, Norma, Moral dan Doktrin Hukum dalam Pertimbangan Putusan Hakim”, Jurnal Cita Hukum. Vol. 2, No. 2, Desember 2014. 
Abraham Lombogia, "Pembebanan Hak Tanggungan Atas Harta Bersama Suami Dan Isteri Dihubungkan Dengan Undang-Undang No. 1 Tahun 1974”, Lex Privatum, Vol. 2, No. 3, Oktober, 2014.

Astriani Van Bone, "Penyelesaian Sengketa Harta Bersama Berstatus Agunan Dalam Perkara Perceraian Di Pengadilan Negeri”, Law Jurnal, Vol. 5, No. 5, Juli 2017.

Bercah Pitoewa, "Kewenangan Komisi Yudisial dalam Rangka Pengawasan Hakim Guna Melaksanakan Amanat UUD 1945”, Jurnal Hukum Fakultas Hukum Universitas Yarsi, Vol.1, No.3, 2013.

Julius Martin Saragih, Yunanto, Herni Widanarti, "Pertanggungjawaban Hutang-Hutang Persatuan Setelah Putusnya Perkawinan”, Diponegoro Law Jurnal, Vol. 6, No. 1, 2017.

\section{Sentence}

Putusan Pengadilan Agama Mataram Nomor 0337/Pdt.G/2017/PA.Mtr, tertanggal 04 Juni 2018.

\section{Regulations}

Undang-Undang Nomor 16 Tahun 2019 tentang Perubahan Atas Undang-Undang Nomor 1 Tahun 1974 tentang Perkawinan, (LN No. 186 Tahun 2019. TLN No. 6401).

Undang-Undang Nomor 48 Tahun 2009 tentang Kekuasaan Kehakiman, (LN No. 157 Tahun 2009, TLN No. 5076).

Undang-Undang Nomor 4 Tahun 1996 tentang Hak Tanggungan, (LN No. 104 Tahun 1960, TLN No. 2043).

Instruksi Presiden Nomor 1 Tahun 1991 tentang Penyebarluasan Kompilasi Hukum Islam, Buku I Hukum Perkawinan, Lembaran Lepas Sekretariat Negara Tahun 1991.

Kitab Undang-Undang Hukum Perdata, (Stbl. 1847-23).

\section{Internet}

Fairus Harris,https://kantorpengacara.co/penyelesaian-kredit-properti-ketika-terjadi-perceraian/, diakses tanggal 12 Januari 2021, Pukul 20.00 WITA.

Isnaini Khoirunisa, https://www.rumah.com/berita-properti/2016/5/125986/beli-properti-sebaiknya-atas-namasuami-atau-istri, diakses tanggal 13 Januari 2021, Pukul 21.30 WITA.

Junadi D. Kamil, https://rumahhokie.com/beritaproperti/rumah-kpr-jadi-harta-gono-gini-setelah-perceraianbegini-penyelesaiannya/, diakses tanggal 13 Januari 2021, Pukul 21.30 WITA. 